\title{
The Market of Energy Capacities: Development and Recent Economic Opportunities
}

\author{
Andrey A. Polukhin, Bella O.Khashir, Andrei N. Osipov, Khatimat N. Gasanova, Elena A. Silko, \\ Svetlana S.Sushentsova
}

\begin{abstract}
The main objective of the study was to assess the market of energy capacities for the development of crop production in Russia. As a result of the study, the dynamics of updating the fleet of agricultural machinery is assessed. Based on a detailed analysis of the intensity of production of energy carriers for crop production in Russia, as well as mechanisms of state support for agricultural engineering, recommendations are given on the formation of import substitution conditions in the markets of self-propelled vehicles in the country. We concluded that the production of crop production, due to its technological specificity, is energy-intensive, from the point of view of the need to provide energy capacities. Self-propelled machinery (self-propelled harvesting equipment - combines, tractors of various draft classes, and other self-propelled machinery for technological operations) form energy capacities in crop production. Based on the analysis, the article shows the availability of energy capacities of agricultural producers, the share of imported equipment as an element affecting food security, offers on the development of the agricultural machinery market in the context of the implementation of the import substitution policy.
\end{abstract}

Keywords: agrarian economy, agricultural engineering, agro-industrial resource markets, agricultural energy efficiency, government support.

\section{INTRODUCTION}

This : the formation of the basis for food security of the

Revised Manuscript Received on November 15, 2019

Andrey A. Polukhin, Federal State Budgetary Scientific Institution "Federal Research Center of Agrarian Economy and Social Development of Rural Areas - All-Russian Research Institute of Agricultural Economics" under Ministry of Science and Higher Education of Russian Federation, Moscow, Russia

Bella O.Khashir, Federal State Budgetary Scientific Institution "Federal Research Center of Agrarian Economy and Social Development of Rural Areas - All-Russian Research Institute of Agricultural Economics" under Ministry of Science and Higher Education of Russian Federation, Moscow, Russia

Andrei N. Osipov, Federal State Budgetary Scientific Institution "Federal Research Center of Agrarian Economy and Social Development of Rural Areas - All-Russian Research Institute of Agricultural Economics" under Ministry of Science and Higher Education of Russian Federation, Moscow, Russia.

Khatimat N. Gasanova, Federal State Budgetary Scientific Institution "Federal Research Center of Agrarian Economy and Social Development of Rural Areas - All-Russian Research Institute of Agricultural Economics" under Ministry of Science and Higher Education of Russian Federation, Moscow, Russia.

Elena A. Silko, Federal State Budgetary Scientific Institution "Federal Research Center of Agrarian Economy and Social Development of Rural Areas - All-Russian Research Institute of Agricultural Economics" under Ministry of Science and Higher Education of Russian Federation, Moscow,Russia.

Svetlana S.Sushentsova, Federal State Budgetary Scientific Institution "Federal Research Center of Agrarian Economy and Social Development of Rural Areas - All-Russian Research Institute of Agricultural Economics" under Ministry of Science and Higher Education of Russian Federation, Moscow, Russia. country is possible only with the intensive development of agricultural engineering. Moreover, this development should be comprehensive and develop all technological elements, as well as all cultivated crops. The peculiarity of Russia is a wide variety of types of agricultural products and conditions of its production. In this regard, the comprehensive development of agricultural machinery is of particular relevance, especially in the implementation of the policy of import substitution in the resource markets.

\section{LITERATURE REVIEW}

Theoretical sources for the development of the problem of development of the market of power capacities for agriculture were modern concepts, Federal and regional programs for the development of the industry, methods of economic evaluation of the efficiency of the use of agricultural machinery. The issues of development of agricultural mechanical engineering is reflected in the writings: Suh K., Suh S., Walseth B., Bae J., Barker R.,[1] Henning, N., Christiansion S., Kofoed'S, [2] Graeme R. Quick, Wesley F. Buchele [3], Dong F., Hennessy D. A., Jensen H. H., Volpe R. J [4], Lapple, D. and Thorne, F. The Role, Bekker, M. G., Collins R. A, Lapple, D. and Thorne, F. [5], N. D. Avarskiy [6], [7], A. G. Papcov [8], V. V. Taran[7]. Problems of increase of efficiency of use of technical potential of agricultural organizations is investigated in the works of: Polukhin A.A [9], [10], Alpatov A. V., Stavtsev A. N.[9], Lisutsenko N. N. [11] Alekseev, K. I., Miroshnikov A. G., Klimova S. P., Parfenov A. S., Fedotenkova O. A., Borkhunov N. A. Polshakova N. V. Altukhov A.V. [9]; Yerseitova, A., Issakova, S., Jakisheva, L., Nauryzbekova, A, Moldasheva, A. 2018 [12]; Vlasov, A.I., Shakhnov, V.A., Filin, S.S., Krivoshein, A.I. [13]. As most scientists, we considered this problem from the standpoint of analyse comparability reasonmag support measures for agricultural engineering and target indicators implemented strategic development programs.

\section{PROPOSED METHODOLOGY}

\section{A. General description}

Research is carried out in the framework of the thematic research plan of GNU FNTS vniiesh. The object of study was the market of energy capacity for the crop industry. Sources of empirical information were official statistics, data from the National report on the implementation of the state Program 2013-2020, data from the Ministry of agriculture of the Russian Federation.

Mathematical and statistical data processing was carried out

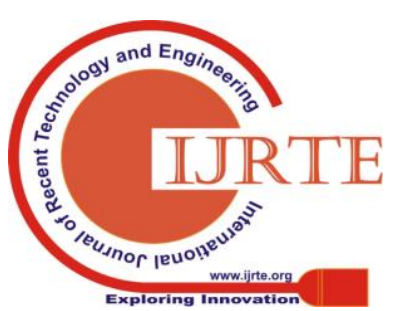


using generally accepted methods of economic analysis. The monographic method, methods of expert assessments, analysis and synthesis were used to substantiate the directions of development.

\section{B. Algorithm}

At the initial stage, a brief comparative analysis of the provision of agriculture in Russia and the EAEU countries with equipment was carried out. Further documents of strategic development of agriculture and agricultural engineering were studied, measures of support and indicators of development were estimated. The study is a logical continuation of the earlier work on the study of the organizational and economic mechanism of energy saving in agriculture $[11,9,10]$ a comparative economic assessment of the energy efficiency of agriculture abroad and in Russia [7].

The impact of measures of state support of agricultural machinery on the development of the industry was assessed. Conclusions are presented and proposals for diversification of targeted support for agricultural machinery in Russia are substantiated.

Table 1: Economic assessment of the presence of the main carriers of the energy capacity of crop production

\begin{tabular}{|l|c|c|c|c|}
\hline \multirow{2}{*}{ Types of equipment } & \multicolumn{2}{|c|}{ Availability of equipment, units* } & \multicolumn{2}{c|}{ Share of foreign-made equipment, \% [4],[15] } \\
\cline { 2 - 5 } & 2017 & 2018 & 2017 & 2018 \\
\hline Tractors & 389831 & 387000 & 68 & 68,8 \\
\hline Combine Harvesters & 130121 & 131188 & 22 & 23 \\
\hline Forage harvesters & 14784 & 14676 & 21 & 21,6 \\
\hline
\end{tabular}

It is important to point out that the Ministry of agriculture of Russia conducts an objective assessment of the shortage of energy capacity for optimal energy supply of agriculture. So the estimated need to upgrade the fleet of agricultural tractors-at least 44, 5 thousand units per year, and the cost of such modernization will be about 180 billion rubles. The assessment was carried out taking into account moral and physical wear of the equipment (the proportion of tractors older than 10 years in the Park of agricultural producers in 2018 amounted to $73,1 \%$, combine harvesters $-64 \%$, forage harvesters $-66,4 \%$, and this percentage is growing every year [4]. In fact, for the period from 2015 to 2018, taking into account state support, about 11 thousand units were purchased annually. new tractors, which of course is extremely insufficient for the comprehensive modernization of the power Park and speaks about the imbalance in the market of equipment in terms of demand and real solvent demand of agricultural producers. A number of authors reveal the role of the market approach in ensuring food security in Russia in an innovative economy. [6] as combine

Table 2: Economic analysis of market niches in the tractor segment by traction classes [15]

\begin{tabular}{|l|c|c|c|}
\hline \multicolumn{1}{|c|}{ Traction class tractors } & Actual availability & Deficit, units & $\begin{array}{c}\text { Deficit in\% of actual } \\
\text { availability, } \%\end{array}$ \\
\hline Traction class0,6-0,9 & 28403 & 4498 & 15,84 \\
\hline Traction class1,4 & 180595 & 23782 & 13,17 \\
\hline Traction class2-3 & 131934 & 26678 & 20,22 \\
\hline Traction class4-5 & 75598 & 20420 & 27,01 \\
\hline Traction class6-7 & 28504 & 9702 & 34,04 \\
\hline Traction class 8 and above & 3302 & 1573 & 47,64 \\
\hline
\end{tabular}

According to the data presented in table 2, it is clear that the largest deficit is observed in the segment of high-power tractors, and one can note sufficient potential for growth in production volumes of Russian-made tractors in this particular segment. However, in quantitative terms, the capacity of the market for medium tractors allows you to harvesters annual assessment need to be updated is in the order of 12,5 thousand units, the actual annual volume of purchase kolebletsja at the level of 5.2 to 6.2 thousand units'.

Subject to the additional requirements in the annual update, according to experts of the Ministry of agriculture of Russia at the end of 2018, the General lack of tractors of different tractive class is 86653 units, which is about $20 \%$ of the availability of tractors, the shortage of combine harvesters -42140 units $(33 \%)$, shortage of forage harvesters - 5603 units $(35 \%)$ [15].

It is important to assess the market of agricultural machinery not so much from the standpoint of quantitative as from the standpoint of qualitative characteristics [16] the use of innovative technology is the material basis of economic stability of agricultural producers [5].

Another important indicator that forms the energy supply for crop production is the structure of the tractor fleet by traction classes. Table 2 presents an analysis of market niches in the tractor segment by traction classes.

increase production and carry out targeted work to conquer the market in this particular segment.

At the same time, it is important to assess the dynamics of development and the potential of agricultural engineering within the country, which is especially important when 
implementing the import substitution policy in resource markets. Table 3 presents data on the production volumes of the main types of agricultural machinery of the Russian

Table 3: Dynamics of production volumes of the main types of agricultural machinery of Russian models, units According to the Ministry of Industry and Trade

\begin{tabular}{|l|c|c|c|c|c|c|}
\hline \multicolumn{1}{|c|}{ Type of equipment, brand } & \multicolumn{3}{c|}{ Years } & \multicolumn{2}{c|}{ Total } \\
\cline { 2 - 6 } & 2013 & 2014 & 2015 & 2016 & 2017 & production \\
\hline Tractors, total units & 7641 & 6394 & 5226 & 6623 & 7063 & 32947 \\
\hline Russian models, total units. & 924 & 1457 & 1840 & 2548 & 2775 & 9544 \\
\hline Kirovets stamps & 327 & 653 & 1337 & 2187 & 1862 & 6366 \\
\hline Stamps "AGROMASH" & 354 & 414 & 160 & 110 & 102 & 1140 \\
\hline Stamps "Terrion" & 83 & 147 & 96 & 68 & 40 & 434 \\
\hline Combine harvesters, total & 6008 & 5652 & 4583 & 6431 & 7273 & 29947 \\
\hline Russian models, total units & 3315 & 3642 & 3758 & 5063 & 5507 & 21285 \\
\hline Stamps "RSM" & 2960 & 3535 & 3706 & 5002 & 5447 & 20650 \\
\hline Stamps "AGROMASH" & 181 & 50 & 52 & 61 & 27 & 371 \\
\hline Forage harvesters, total units & 642 & 522 & 619 & 988 & 689 & 3460 \\
\hline Russian models, total units & 402 & 390 & 509 & 805 & 530 & 1831 \\
\hline Rostselmash & 190 & 107 & 261 & 313 & 286 & 844 \\
\hline Clever & 194 & 246 & 229 & 383 & 232 & 1284 \\
\hline
\end{tabular}

According to the data presented in table 3, it is clear that only $29 \%$ of tractors produced in Russia are Russian models, and $2 / 3$ of them are Kirovets brands. In this regard, the issue of expanding the brand composition of Russian tractors produced and occupying new market niches is of particular relevance. $71 \%$ of Russian-made grain harvesters and $53 \%$ of

Table 4: Dynamics of production volumes of the main types of agricultural machinery of Belarusian models and models of far-abroad countries, units

\begin{tabular}{|c|c|c|c|c|c|c|}
\hline \multirow{2}{*}{ Type of equipment, brand } & \multicolumn{5}{|c|}{ Years } & \multirow{2}{*}{$\begin{array}{c}\text { Total } \\
\text { production }\end{array}$} \\
\hline & 2013 & 2014 & 2015 & 2016 & 2017 & \\
\hline \multicolumn{7}{|c|}{ Tractors } \\
\hline Joint production with the Republic of Belarus, total units & 3914 & 2729 & 2330 & 2985 & 2546 & 14504 \\
\hline TD MTZ-ELAZ (Tatarstan) & 2238 & 928 & 588 & 742 & 137 & 4633 \\
\hline Buzuluk Mechanical Plant (Orenburg Region) & 177 & 436 & 214 & 383 & 167 & 1377 \\
\hline Cherepovets Foundry and Mechanical Plant (Vologda Oblast) & 137 & 271 & 1253 & 1824 & 1546 & 5031 \\
\hline Foreign models, total units & 2803 & 2208 & 1056 & 1090 & 1742 & 8899 \\
\hline "John Deere Rus" (Moscow region) & 883 & 680 & 67 & 176 & 246 & 2052 \\
\hline Brands "Versatile" (Rostselmash) & 236 & 262 & 88 & 74 & 648 & 1308 \\
\hline Klaas stamps (Krasnodar Territory) & 289 & 238 & 228 & 414 & 192 & 1361 \\
\hline SIENEICH-KAMAZ-INDUSTRY (Republic of Tatarstan) & 273 & 170 & 60 & 126 & 238 & 867 \\
\hline TD KhTZ (Belgorod Region) & 942 & 858 & 535 & 123 & 418 & 2876 \\
\hline \multicolumn{7}{|c|}{ Combine harvesters } \\
\hline oint production with the Republic of Belarus, total units & 1764 & 1255 & 711 & 1050 & 1101 & 5881 \\
\hline Bryanskselmash (Bryansk region) & 1620 & 1117 & 550 & 975 & 1101 & 5363 \\
\hline Foreign models, total units & 929 & 755 & 114 & 318 & 665 & 2781 \\
\hline "John Deere Russia" (Moscow region) & 168 & 111 & 8 & 67 & 151 & 505 \\
\hline Klaas (Krasnodar Territory) & 523 & 406 & 79 & 225 & 466 & 1699 \\
\hline SIENEICH-KAMAZ-INDUSTRIYA (Republic of Tatarstan) & 221 & 229 & 27 & 26 & 48 & 551 \\
\hline \multicolumn{7}{|c|}{ Forage harvesters } \\
\hline Joint production with the Republic of Belarus, total units & 240 & 132 & 110 & 183 & 159 & 824 \\
\hline Bryanskselmash (Bryansk region) & 240 & 132 & 110 & 183 & 159 & 824 \\
\hline
\end{tabular}

According to the Ministry of Industry and Trade

The information presented in table 4 indicates the dominance of Belarusian brands of tractors in the Russian market. It should also be noted that the world leaders in agricultural engineering localize their production on the territory of Russia, which can significantly reduce the cost of equipment entering the market.

\section{DISCUSSION}

An important factor in the development of agricultural engineering and the intensification of technical
Russian-made forage harvesters. The leader in the combine market is the Rosselmash plant. Table 4 presents data on production volumes of the main types of agricultural machinery of Belarusian and foreign models.$$
\text { machinery of Belarusian and foreign models. }
$$

models. 
this equipment. The implementation of the subsidy program allowed to increase the production of machinery at 70 agricultural engineering enterprises in 37 constituent entities of the Russian Federation. For example, in 2017 - 2018, 25.7 billion rubles were allocated for agribusiness entities in this area of state support, that is, ensuring the sale of agricultural machinery of Russian production with a significant discount.

Starting from 2018, the state has provided a federal subsidy (Decree of the Government of the Russian Federation No. 145 dated February 10, 2018) to compensate for part of the costs associated with the issue and support of warranty obligations for high-performance agricultural self-propelled and trailed equipment in the amount of 9 billion rubles, which also allowed to stimulate the development of agricultural engineering in the segments of high-performance equipment.

Modernization of the equipment fleet for agricultural producers is a high-cost event, and in this regard, the availability of borrowed funds is an important aspect. State support is also being provided in this area, for example, in the framework of Decree of the Government of the Russian Federation No. 163 dated February 17, 2018, it was realized using the preferential interest rate on loans for the purchase of agricultural machinery (about 5\%) in the amount of more than 2 billion rubles. [7], [15]

At the same time, according to the Ministry of Industry and Trade of Russia, foreign agricultural machinery is purchased by farmers through subsidies from regional budgets in more than 50 constituent entities of the Russian Federation, up to 8 billion rubles are provided annually for these purposes.

\section{CONCLUSION}

Foreign experience of state support for agricultural machinery manufacturers shows that in most countries of the world the targeted mechanism for supporting the agricultural engineering industry is not applied, but is part of a comprehensive mechanism for supporting the engineering sector. In Russia, the comprehensiveness of the measures taken to support domestic producers of agricultural machinery has allowed agricultural machinery to be overcome from the crisis, but the lack of support for agricultural producers has an impact on the slowdown in the renewal of the agricultural machinery fleet. It is also necessary to more intensively financially support manufacturers of energy-intensive and energy-efficient equipment using precision farming systems and digital technologies.

\section{REFERENCES}

1. Suh K., Suh S., Walseth B., Bae J., Barker R. "Optimal corn stover logistics for biofuel production: a case in Minnesota", Transactions American Society of Agricultural Engineers: General Edition, 54 (1), 2011, pp. 229-238.

2. Henning, N., Christiansion S., Kofoed'S “A split-power approach: the M. S. and tractor system", Just of agricultural Engineering, Roal veterinary and agricultural University, 31, 1977.

3. Graeme R. Quick, Wesley F. Buchele "The Grain Harvesters. American Society of Agricultural Engineers", St. Joseph: Michigan, 1978.

4. Dong F., Hennessy D. A., Jensen H. H., Volpe, R. J. "Technical efficiency, herd size, and exit intentions in U. S. dairy farms", Journal of Agricultural Economics, 47, 2016, pp. 777-545. https://doi.org/10.1111/agec.12253.

5. Lapple, D. and Thorne, F. "The Role of Innovation in Farm Economic Sustainability: Generalized Propensity Score Evidence from Irish Dairy
Farms", Journal of Agricultural Economics, 70, (1), 2019, pp. 178-197. https://doi: 10.1111/1477-9552.12282

6. Nuraliev S. U., Veselovsky M. Y., Fedotov, A. V., Sandu, I. S., Avarskiy, N. D. "Role of wholesale market in russian ensuring food safety under conditions of innovative economy", Journal of Applied Economic Sciences, Vol. X, 3 (33), 2015, pp. 419-427.

7. Taran V. V., Magomedov A-N. D., SokolovaZh. E. "Energy efficiency of agriculture abroad and in Russia", Agriculture: Economics, management, 7, 2011, pp. 83-88.

8. Paptsov A. G. "Areas of global food security". APK: Economy, management, 10, 2015, pp. 103-107.

9. Polukhin A. A., Alpatov A. V., Stavtsev A. N., Alekseev, K. I., Miroshnikov A. G., Klimova S. P., Parfenov A. S., Fedotenkova O. A., Borkhunov N. A. Polshakova N. V. Altukhov A.V. "Organizational-economic bases of energy conservation in agriculture", Eagle: Cartouche publishing house, 2013, p. 132

10. Polukhin A. A. "Approaches for justification strategy technical modernization of agriculture given the characteristics of agricultural development and resource provision subjects of the federation", Russian Journal of Agricultural and Socio-Economic Sciences, 24 (12), 2013, pp. 22-27.

11. Polukhin A. A., Lisutsenko N. N. "Organizational and economic bases of energy conservation in agriculture", Russian Journal of Agricultural and Socio-Economic Sciences, 4 (4), 2012 pp. 20-26 http://www.rjoas.com/issue-2012-04.html

12. Yerseitova, A., Issakova, S., Jakisheva, L., Nauryzbekova, A, Moldasheva, A. "Efficiency of using agricultural land in Kazakhstan", Entrepreneurship and Sustainability Issues, 6 (2), 2018, pp. 558-576. http://doi.org/10.9770/jesi.2018.6.2(7)

13. Vlasov, A.I.; Shakhnov, V.A.; Filin, S.S.; Krivoshein, A.I. "Sustainable energy systems in the digital economy: concept of smart machines", Entrepreneurship and Sustainability Issues, 6 (4), 2019, pp. 1975-1986. http://doi.org/10.9770/jesi.2019.6.4(30)

14. VDMA, Eurostat, Branchen - und MarktentwicklungfürLandtechnik. Deutschland/Europa/Welt, Dezember 2012 VDMA www.vdma.org/landtechnik.

15. National report on the progress and results of the implementation in 2018 of the State program for the development of agriculture and regulation of markets for agricultural products, raw materials and food. approved. By order of the government of the Russian Federation from 22.06.2019 No. 1352-R

16. Bekker, M. G., Collins R. A. "Comparison of tractors rear types in their resistance to sideslip", Journal of agricultural Engineering research, 17 (1), 1972, pp.20-23 